\title{
Techno-economic and resource analysis of hydroprocessed renewable jet fuel
}

\author{
Ling Tao* (i), Anelia Milbrandt, Yanan Zhang and Wei-Cheng Wang
}

\begin{abstract}
Background: Biomass-derived jet fuel is an alternative jet fuel (AJF) showing promise of reducing the dependence on fossil fuel and greenhouse gas emissions. Hydroprocessed esters and fatty acids (HEFA) concept is also known as one of the pathways for producing bio jet fuel. HEFA fuel was approved by the American Society for Testing and Materials in 2011, and can be blended up to 50\% with conventional jet fuel. Since then, several HEFA economic and life-cycle assessments have been published in literature. However, there have been limited analyses on feedstock availability, composition, and their impact on hydrocarbon yield (particularly jet blendstock yield) and overall process economics.

Results: This study examines over 20 oil feedstocks, their geographic distribution and production levels, oil yield, prices, and chemical composition. The results of our compositional analysis indicate that most oils contain mainly $\mathrm{C}_{16}$ and $\mathrm{C}_{18}$ fatty acids except pennycress, yellow grease, and mustard, which contain higher values and thus would require hydrocracking to improve jet fuel production. Coconut oil has a large content of shorter carbon fatty acids, making it a good feedstock candidate for renewable gasoline instead of jet substitutes' production. Techno-economic analysis (TEA) was performed for five selected oil feedstocks — camelina, pennycress, jatropha, castor bean, and yellow grease-using the HEFA process concept.

Conclusion: The resource analysis indicates that oil crops currently grown in the United States (namely soybean) have relatively low oil yield when compared to oil crops grown in other parts of the world, such as palm, coconut, and jatropha. Also, non-terrestrial oil sources, such as animal fats and greases, have relatively lower prices than terrestrial oil crops. The minimum jet fuel selling price for these five resources ranges between $\$ 3.8$ and $\$ 11.0$ per gallon. The results of our TEA and resource studies indicate the key cost drivers for a biorefinery converting oil to jet hydrocarbons are as follows: oil price, conversion plant capacity, fatty acid profile, addition of hydrocracker, and type of hydroprocessing catalysts.
\end{abstract}

Keywords: Techno-economics analysis, Feedstock, Hydroprocessed renewable jet fuel, Alternative jet fuel, Resources, Lipids

\section{Background}

Aviation fuel has more stringent quality requirements and fuel specifications than fuels used in road transportation. Jet fuel is a type of aviation fuel designed specifically to power gas-turbine engines. According to a report from the United States (US) Energy Information Administration (EIA) [1], about $10 \%$ of each barrel (42 gallons per barrel) of crude oil is used to produce jet fuel. The worldwide aviation industry consumes approximately 63-134

*Correspondence: ling.tao@nrel.gov

National Renewable Energy Laboratory, 15013 Denver West Parkway, Golden, CO 80401, USA billion gallons of conventional jet fuel per year $[2,3]$. Based on the 2015 estimates from the EIA, jet fuel consumption in the transportation sector in the US is 23.7 billion gallons, and expenditures for this fuel are $\$ 39$ billion dollars [4]. Fuel is the largest operating cost in the aviation industry, and the unstable prices of crude oil hamper long-term planning and expense budgeting. Jet fuel from renewable sources such as biomass can reduce the dependency of the aviation industry on one single energy source, potentially reducing the risk of the petroleum prices volatility [5], and potentially reducing greenhouse gas (GHG) emissions [2]. For the US Department 
of Defense alternative fuel initiatives, the US Air Force has set goals to test and certify all aircrafts and systems on a 50:50 alternative fuel blend and to ensure that 50\% of the domestic aviation fuel used by the Air Force comes from an alternative fuel blend by $2025[6,7]$. The US Navy's goal is to run ships and aircraft entirely on alternative fuel blends and to achieve $50 \%$ of the Navy's total energy use from alternative sources by 2020 [6].

Technical certification of alternative fuels is primarily led by the American Society for Testing and Materials (ASTM) with support from the Commercial Aviation Alternative Fuels Initiative and the US Air Force. Certain biojet fuels can now be blended up to $50 \%$ with conventional commercial and military jet (or aviation turbine) fuel $[8,9]$. These include Fischer-Tropsch fuels using solid biomass resources; hydroprocessed esters and fatty acids (HEFA) fuels derived from used cooking oil, animal fats, algae, and vegetable oils; and alcohol-to-jet fuels produced from isobutanol and blended to a maximum level of $30 \%$.

HEFA fuel properties are similar to conventional petroleum fuel, but the fuel has the advantages of a higher cetane number, lower aromatic content, lower sulfur content, and potentially lower GHG emissions [10]. The hydroprocessing conversion technologies (e.g., hydrotreating, deoxygenation, isomerization, and hydrocracking) are at a relatively high maturity level and are commercially available. These processes are commonly used in today's refineries to produce transportation fuels. Since 2008, many test flights using HEFA fuel from various oil-based feedstocks (e.g. jatropha, algae, camelina, and yellow grease) have been conducted by military and commercial entities [11-19]. Neste Oil and Honeywell Universal Oil Products (UOP) are one of the leading companies producing HEFA fuel for the aviation biofuels market [20-23].

There are a few economic analyses of HEFA fuel in literature $[8,24]$. While there is some information on feedstock availability and composition, there is a general lack of understanding of their impact on hydrocarbon yield (particularly jet blendstock yield) and overall process economics. The goal of this study is to improve the understanding of HEFA fuel economics and thus support future development of this technology. To achieve this goal, we defined three objectives: (1) conduct a resource assessment that evaluates the geographic distribution and production levels of major oil sources, their oil yield, and prices; (2) analyze the chemical composition of oil feedstock, namely their free fatty acid (FFA) profile; and (3) conduct a comprehensive but comparative technoeconomic analysis (TEA) on five selective oil feedstocks. The market will ultimately decide which resources would be used for what purposes. Our paper only states the possibilities and serves as a reference if these feedstocks are used for biofuels production. TEA is an essential and powerful tool used to understand economic potential of a technology strategy, effectively prioritize research directions, and suggest new research toward an economically viable process strategy.

\section{Methods}

\section{Resource analysis}

We examined over 20 sources for HEFA production as summarized in Table 1. Our primary focus was on sources applicable to the US, although some additional feedstocks were included due to their import in the country, importance in the international oilseed market, or receiving global attention as an emerging biofuel feedstock. Price and yield data for these sources were

\section{Table 1 Sources for hydroprocessed renewable jet fuel}

\begin{tabular}{|c|c|}
\hline \multicolumn{2}{|l|}{ Vegetable oil } \\
\hline Palm/Palm kernel & Elaeis guineensis \\
\hline Coconut & Cocos nucifera \\
\hline Jatropha & Jatropha curcas \\
\hline Castor & Ricinus communis \\
\hline Rapeseed & Brassica napus \\
\hline Canola & Brassica napus, cultivar \\
\hline Pennycress & Thlaspiarvense \\
\hline $\begin{array}{l}\text { Peanut (ground- } \\
\text { nut) }\end{array}$ & Arachis hypogaea \\
\hline Sunflower & Helianthus annuus \\
\hline Safflower & Carthamus tinctorius \\
\hline Camelina & Camelina sativa \\
\hline Mustard & Brassica juncea \\
\hline Linseed (flax) & Linum usitatissimum \\
\hline Soybean & Glycine max \\
\hline Cottonseed & Gossypium hirsutum \\
\hline Corn & Zeamays \\
\hline \multicolumn{2}{|l|}{ Animal fats } \\
\hline Lard & Edible pork fat, rendered and unrendered \\
\hline $\begin{array}{l}\text { Choice white } \\
\text { grease }\end{array}$ & Inedible pork fat derived primarily from pork tissue \\
\hline Edible tallow & Beef fat suitable for human consumption \\
\hline Inedible tallow & Beef fat unsuitable for human consumption \\
\hline Poultry fat & $\begin{array}{l}\text { Fat obtained from chicken rendering and process- } \\
\text { ing }\end{array}$ \\
\hline \multicolumn{2}{|l|}{ Grease } \\
\hline Yellow grease & $\begin{array}{l}\text { Derived from used cooking oil generated by com- } \\
\text { mercial and industrial cooking operations. It may } \\
\text { also contain rendered animal fat }\end{array}$ \\
\hline Brown grease & $\begin{array}{l}\text { Waste grease recovered from traps installed in } \\
\text { the sewage lines of restaurants/food processing } \\
\text { plants and wastewater treatment plants. }\end{array}$ \\
\hline \multicolumn{2}{|c|}{ Aquatic microorganisms } \\
\hline Algae & $\begin{array}{l}\text { A large group of simple plant-like photosynthetic } \\
\text { organisms }\end{array}$ \\
\hline
\end{tabular}


gathered and analyzed. Data providers included the US Department of Agriculture (USDA), consulting agencies, and private companies engaged in feedstock production or distribution. For most feedstocks, the 2014 annual average price was obtained. For feedstocks with a missing of 2014 price information, we used the most recent data at a given point in time (within the 2012-2013 timeframe) or model-derived estimates. Information on the average yield for the reviewed oil crops was also gathered. We recognized that crop yields vary under different agro-climatic conditions but for the purpose of this study, we assumed that the average value was a reasonable proxy for the midpoint of a yield range. We were unable to conduct sensitivity analyses with low and high yield at this time. In addition to these activities, we gathered data on production of the major oil crops in the US and a map was generated to illustrate the geographic distribution of these resources by county.

Five oil sources were selected for the TEA: camelina, pennycress, jatropha, castor bean, and yellow grease. The five sources were selected for the following reasons: non-food feedstocks (pennycress and castor bean), promising for the US agro-climatic conditions (camelina, pennycress, and castor bean), low cost and readily available (yellow grease), receiving global attention (jatropha), and high yield among terrestrial plants (jatropha and castor bean). Additionally, some of these sources were less studied as potential jet fuel feedstock (e.g., pennycress and castor bean), thus we saw an opportunity for this study to improve the knowledge base for these feedstocks. Moreover, alternative jet fuel (AJF) produced from camelina oil, jatropha oil, and yellow grease has been tested in aircrafts, which indicated market interest in these sources [24]. Algae was also considered a promising biofuel feedstock but it was not included in our analysis because there have been many other studies on algae productivity and economics over the years [25-31]. Below is a brief description of the five selected oil sources.

Camelina is an annual flowering plant (commonly known as gold-of-pleasure or false flax) of the Brassicaceae family that includes the well-known oil crops rapeseed, canola, and mustard. Camelina has a high oil content (about 35\% oil) and improved drought tolerance and water use efficiency (yield vs. evapotranspiration) when compared to other oilseed crops [32]. These characteristics make camelina a suitable biofuel crop for the arid western states, an area generally lacking opportunities for growing biofuel feedstock. Camelina production requires low agricultural input and the same equipment as wheat and thus fits well into a dryland crop rotation; it could replace fallow, provide an energy crop, and would not compete with food crops production [33]. Because camelina oil is high in omega-3 fatty acids, perceived to have health benefits, it is considered high-quality edible oil. This may lead to feedstock competition between the biofuels and the food industries as well as high feedstock prices.

Pennycress, also known as stinkweed or French-weed, is a winter annual belonging to the Brassicaceae family. It has been growing as a weed in the Midwest but there have been efforts to cultivate it in recent years. The plant has potential to serve in a summer/winter rotational cycle with conventional commodity crops (such as corn or soybean), thus not displacing existing agricultural production [34]. Field pennycress is tolerant of fallow lands, requires minimal agricultural inputs (fertilizer, pesticides, water), it is a non-food crop, it is compatible with existing farm infrastructure, and has high oil content (up to $36 \%$ oil) [34]. The plant has been researched by the USDA and other organizations such as the plant science startup Arvegenix, a leading developer of field pennycress, focused on the genetic improvement and commercialization of the plant.

Jatropha is a tropical perennial shrub that has received a lot of attention in recent years. This multipurpose plant is already used as a live fence and to control erosion; the oil extracted from the seeds (about 35\% or more) is used for medicinal purposes and soap making; and the seedcake is used as organic fertilizer and animal feed [35]. Some 10 years ago, the plant's oil was targeted as feedstock for biofuels production or a direct substitute for petroleum diesel in power generators. Jatropha was promoted as a drought-resistant, low-input plant, able to deliver highquality biofuel on marginal lands [36]. Labeled as a "miracle crop" [37-39], the plant attracted large investments. However, jatropha lost its appeal during the recession as farmers realized that the yield is far lower than predicted. Jatropha may hold potential for biofuels production but there are many uncertainties surrounding its cultivation; primarily because while it grows abundantly in the wild, it has never been domesticated. Recently, SGB, an agricultural biotechnology company, claimed to have succeeded in domesticating the plant through advances in molecular genetics and DNA sequencing technology, a process that once took decades [40].

Yellow grease is essentially rendered used cooking oil (restaurant grease) that meets the following specifications: FFA maximum of $15 \%$ and moisture, impurities, and unsaponifiables of less than 2 with $1 \%$ maximum water [41]. Yellow grease is a commodity in the US and has recently become increasingly valuable since it is now used for production of biofuels. Historically, it has been used as an animal feed additive, for production of plastics, textiles, and cosmetics, in soap making, and as a lubricant. Yellow grease is an attractive feedstock for the 
biofuels industry because it is readily available and relatively inexpensive.

Castor bean is a perennial plant in tropical and subtropical regions and can be grown as an annual in colder climates. Castor oil is essential to the chemical industry because it is the only commercial source of hydroxylated fatty acids (HFA) - ricinoleic acid (C18:1-OH). It is used in paints, coatings, inks, lubricants, and a wide variety of other products [42]. Due to a combination of economic factors, allergenic reactions associated with growing and processing the plant, and toxicity of the seed meal (the seeds contain ricin, a toxic protein), production in the United States ceased in the early 1970s, and currently the industry depends on imports, primarily from India. Despite the controversy surrounding its production, there is a growing interest in domestic castor production because of reported high oil yield and suitability on marginal lands. Researchers at Texas AgriLife Extension reported oil yield at about $50 \%$ and found castor to be drought and salt tolerant, therefore a suitable oil crop for select areas of Texas and potentially the whole Southwest [43]. Researchers at the University of California-Davis are also testing castor as a potential feedstock for biofuels production [43]. Efforts to reduce toxicity and make the plant safe are underway at Texas Tech University and Mississippi State University [43, 44].

There are other potential oil crops for HEFA including Lesquerella (Lesquerella fendleri), Cuphea (Cuphea spp., C. Viscosissima), and Crambe (Crambe abyssinica). Lesquerella, commonly known as bladderpod, is a native plant to the southwestern United States and Mexico. This crop is desirable due to the high level of HFA in the oil, lesquerolic acid $(\mathrm{C} 20: 1-\mathrm{OH})$, similar to that in castor oil but without the toxic ricin. Thus, it could be a safer alternative to the imported castor oil. Similar to castor, lesquerella methyl esters have been shown to increase lubricity in ultra-low sulfur diesel at concentrations as low as $0.25 \%$ [45]. Cuphea (also known as blue waxweed, clammy cuphea, or tarweed) is a plant native to the Americas, adapted to the temperate regions. The plant species offers high levels of medium-chain fatty acids $\left(\mathrm{C}_{8}-\mathrm{C}_{12}\right)$ used in the production of lubricants, soaps, detergents, cosmetics, and personal-care products, and is currently supplied in the US by imported coconut and palm oil [46]. Therefore, the plant offers a domestic alternative to these tropical sources and a business opportunity for farmers in the temperate climate for no other temperate oilseed crop has been found to provide these lipids [46]. Moreover, cuphea oil is reported to have low viscosity, which makes it suitable for direct use as fuel-petroleum diesel blends with cuphea oil performed well in engine durability tests [46]. Crambe, also known as Abyssinian kale, is believed to be of Mediterranean origin and has been grown in a wide range of climatic conditions [47]. There has been limited production in the United States, mostly in North Dakota, since 1990 [48]. The seed oil of crambe is non-edible and contains a high level of erucic acid, an important feedstock for the oleo-chemical industry. Crambe is reported to have high yield potential, resistance to insect feeding (possibly due to high glucosinolate content), and more tolerance than canola to abiotic stress such as salinity, cold temperature, heat and drought, and heavy metal exposure [47]. These less-known oil crops were not included in the TEA.

\section{Process design}

Although feedstocks for HEFA processes include natural oils derived from plants, animal fats, post-consumer wastes (e.g., yellow grease), and aquatic microorganisms such as algae and cyanobacteria, the generic process concept is very similar. A representative process flow diagram is shown in Fig. 1, including processes of hydrogenation, propane cleave, hydrocracking and hydroisomerization, and product fractionation.

Bio-oils are sent to the hydroprocessing facility (first block in Fig. 1), fundamentally with three reaction steps-hydrogenation, propane cleave, and decarboxylation-according to patents by UOP and Syntroleum $[49,50]$. First, catalytic hydrogenation could be used to convert liquid-phase unsaturated FFAs or glycerides into saturated with the addition of hydrogen $\left(\mathrm{H}_{2}\right)$ [51]. Hydrogenation takes place to saturate the double bonds in the unsaturated triglycerides [52]. The reaction equations are [52]:

$$
\begin{aligned}
& \text { triolein }+3 \mathrm{H}_{2} \rightarrow \text { tristearin } \\
& \text { trilinolein }+6 \mathrm{H}_{2} \rightarrow \text { tristearin } \\
& \text { trilinolenin }+9 \mathrm{H}_{2} \rightarrow \text { tristearin }
\end{aligned}
$$

The second step is to cleave the propane and produce three moles of FFAs [10] per mole of triglycerides. The glycerol portion of the triglyceride molecule is converted into propane by adding $\mathrm{H}_{2}$. The propane cleave process removes the propane backbone from the molecule, turning glycerides into three fatty acids, shown in Eqs. 4-9:

$$
\begin{aligned}
& \text { trimyristin }+3 \mathrm{H}_{2} \rightarrow 3 \mathrm{C}_{14} \mathrm{H}_{27} \mathrm{COOH}+\mathrm{C}_{3} \mathrm{H}_{8} \\
& \text { tripalmitin }+3 \mathrm{H}_{2} \rightarrow 3 \mathrm{C}_{16} \mathrm{H}_{31} \mathrm{COOH}+\mathrm{C}_{3} \mathrm{H}_{8} \\
& \text { tristearin }+3 \mathrm{H}_{2} \rightarrow 3 \mathrm{C}_{18} \mathrm{H}_{35} \mathrm{COOH}+\mathrm{C}_{3} \mathrm{H}_{8} \\
& \text { triarachidin }+3 \mathrm{H}_{2} \rightarrow 3 \mathrm{C}_{20} \mathrm{H}_{39} \mathrm{COOH}+\mathrm{C}_{3} \mathrm{H}_{8} \\
& \text { tribehenin }+3 \mathrm{H}_{2} \rightarrow 3 \mathrm{C}_{22} \mathrm{H}_{43} \mathrm{COOH}+\mathrm{C}_{3} \mathrm{H}_{8}
\end{aligned}
$$




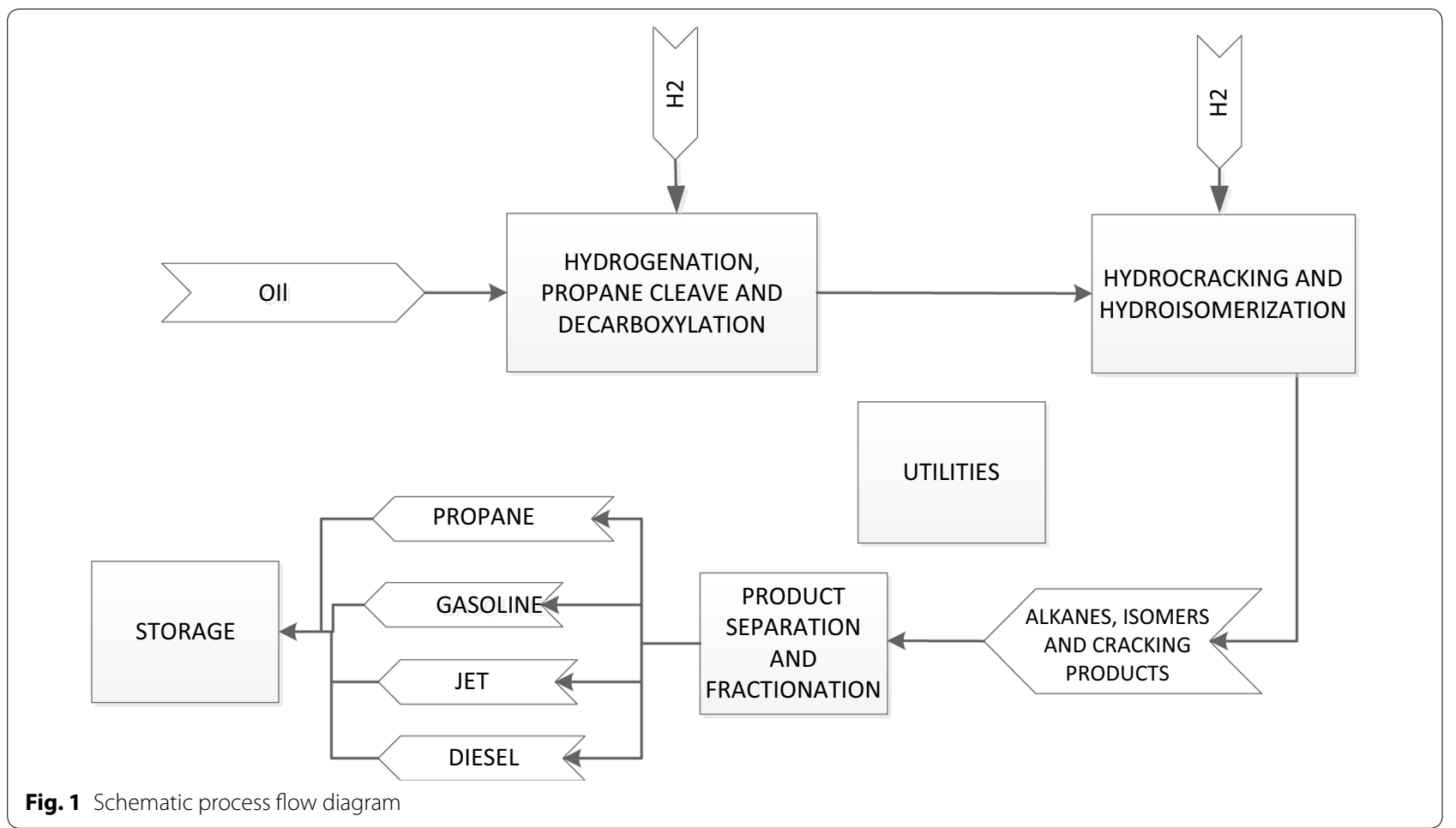

$$
\text { trilignocerin }+3 \mathrm{H}_{2} \rightarrow 3 \mathrm{C}_{24} \mathrm{H}_{47} \mathrm{COOH}+\mathrm{C}_{3} \mathrm{H}_{8}
$$

The third reaction is to remove the oxygen from the fatty acids [53]. There are three pathways occurring in this stage: decarboxylation, decarbonylation, and hydrodeoxygenation. The decarboxylation pathway removes oxygen in the form of carbon dioxide $\left(\mathrm{CO}_{2}\right)$, decarbonylation removes oxygen in the form of carbon monoxide (CO), and hydrodeoxygenation removes oxygen in the form of $\mathrm{H}_{2} \mathrm{O}$. Decarboxylation is chosen in this study, using Eqs. 10-15, while other mixed decarboxylation and hydrodeoxygenation are studied in the sensitivity analysis.

$$
\begin{aligned}
& \mathrm{C}_{14} \mathrm{H}_{27} \mathrm{COOH} \rightarrow \mathrm{C}_{13} \mathrm{H}_{28}+\mathrm{CO}_{2} \\
& \mathrm{C}_{16} \mathrm{H}_{31} \mathrm{COOH} \rightarrow \mathrm{C}_{15} \mathrm{H}_{32}+\mathrm{CO}_{2} \\
& \mathrm{C}_{18} \mathrm{H}_{35} \mathrm{COOH} \rightarrow \mathrm{C}_{17} \mathrm{H}_{36}+\mathrm{CO}_{2} \\
& \mathrm{C}_{20} \mathrm{H}_{39} \mathrm{COOH} \rightarrow \mathrm{C}_{19} \mathrm{H}_{40}+\mathrm{CO}_{2} \\
& \mathrm{C}_{22} \mathrm{H}_{43} \mathrm{COOH} \rightarrow \mathrm{C}_{21} \mathrm{H}_{44}+\mathrm{CO}_{2} \\
& \mathrm{C}_{24} \mathrm{H}_{47} \mathrm{COOH} \rightarrow \mathrm{C}_{23} \mathrm{H}_{48}+\mathrm{CO}_{2}
\end{aligned}
$$

The reaction temperature and pressure for the combined step of hydrogenation, propane cleave, and decarboxylation, are $400{ }^{\circ} \mathrm{C}$ and 9.2 megapascal (resulting in the total conversion of $91.9 \%[52,54]$. The catalyst used in this process is $\mathrm{Pd} / \gamma-\mathrm{Al} 2 \mathrm{O} 3$ and the catalyst-tooil ratio is 0.088 . The $\mathrm{H}_{2}$ gas is fed into the reactor for the hydrogenation and propane cleave. The $\mathrm{H}_{2}$ usage is calculated based on the $\mathrm{H}_{2}$ required for saturating the double bonds of the unsaturated triglycerides and cleaving the propane from the glycerol backbone $[52,53]$. For instance, for every mole of triolein, trilinolein, and trilinolenin, 3, 6, and $9 \mathrm{~mol}$ of $\left(\mathrm{H}_{2}\right)$ would be required, respectively. In addition, for removing the propane molecule from the triglycerides, $3 \mathrm{~mol}$ of $\mathrm{H}_{2}$ are required $[52,53]$ per mole of triglycerides. The resulting products contain liquid hydrocarbons and gas products, including $\mathrm{CO}_{2}, \mathrm{H}_{2}$ and propane. The gas is purged and is sent to a vapor-liquid separator to remove the gas phase products. The liquid portion is routed to the second block (shown in Fig. 1). The second hydrotreating step includes hydrocracking and hydroisomerization reactions. To meet the jet fuel specification, the produced AJF has to have not only a high flash point, but also good cold flow properties. Therefore, with the addition of a processing step of hydrocracking and hydroisomerization, the normal paraffins produced from deoxygenation convert to a synthetic paraffinic kerosene (SPK) product [51]. The cracking and isomerization reactions are either concurrent or sequential [51]. Studies have shown that isomerization of straight-chain alkanes occur first and cracking is a sequential reaction. The isomerization 
process takes the straight-chain hydrocarbons and turns them into the branched structures to reduce the freeze point to meet the jet fuel standard [55]. It is accompanied by a hydrocracking reaction, which results in minimum yield loss from the isomerized species. Sometimes the hydroisomerization will accompany cracking, which reduces the chain length and produces more molecules. The hydroisomerization/cracking reaction is operated at a temperature of $355{ }^{\circ} \mathrm{C}$, pressure of $600 \mathrm{lb}$ per square inch gage, an liquid hourly space velocity of $1\left(\mathrm{~h}^{-1}\right)$, and a $\mathrm{H}_{2} /$ feed ratio of 50 standard cubic feet/gal $[50,56]$. The catalyst can be selected as $\mathrm{Pt} / \mathrm{HZSM}-22 / \gamma$ - Al2O3 [52]. The product distribution and mass yield are based on Abhari's work [50]. In this case, large molecules are assumed to crack into small ones and then become partially isomerized, as shown in Eq. 16.

$$
n \text {-alkanes } \rightarrow n \text {-alkanes }+ \text { isomers }
$$

Bifunctional catalysts containing metallic sites for hydrogenation/dehydrogenation and acid sites for selective isomerization via carbenium ions could be used in isomerization [57]. In a typical isomerization reaction, normal paraffins are dehydrogenated on the metal sites of the catalyst and react on the acid sites to produce olefins protonate with formation of the alkylcarbenium ion. The alkylcarbenium ion is rearranged to monobranched, dibranched, and tribranched alkylcarbenium ions on the acid site. The branched alkylcarbenium ions are deprotonated and hydrogenated to produce the corresponding paraffins [58]. The choice of catalyst will result in variation of cracking at the end of the paraffin molecule and, therefore, adjust the yield of jet blendstocks [51]. This study assumed that the catalyst is used with a weight hourly space velocity (WHSV) of $2 \mathrm{~h}^{-1}$, and is replaced every half year.

The hydroisomerization and hydrocracking processes are followed by a fractionation process to separate the mixtures to paraffinic kerosene, paraffinic diesel, naphtha, and light gases. The hydrocracking reactions are exothermic and result in the production of lighter liquids and gas products. They are relatively slow reactions; thus, most of the hydrocracking takes place in the last section of the reactor. The hydrocracking reactions primarily involve cracking and saturation of paraffins. Over-cracking will result in low yields of jet-fuel-range alkanes and high yields of light species ranging from $C_{1}$ to $C_{4}$, and naphtha ranging from $\mathrm{C}_{5}$ to $\mathrm{C}_{8}$. The bi-functional catalysts used for isomerization contain platinum-containing zeolite catalysts at $1 \mathrm{~h}^{-1}$ WHSV in the $250{ }^{\circ} \mathrm{C}$ fixed bed reactor similar to the hydrotreating step. Hydroisomerization catalyst life is assumed 5 years, and an atmosphere of $\mathrm{H}_{2}$ is used to minimize carbon deposits on the catalyst but $\mathrm{H}_{2}$ consumption is negligible.
In the TEA model, $\mathrm{C}_{15}-\mathrm{C}_{23}$ compounds are modeled to be hydrocracked completely to a mixture of hydrocarbons. For instance, if the compound is $\mathrm{C}_{15}$, the mixture of hydrocarbons ranges from $\mathrm{CH}_{4}$ to $\mathrm{C}_{14}$. Both of these are not ideal jet fuel range hydrocarbons and also potentially have lower economic value than diesel or jet fuel.

\section{Product separation and fractionation}

Unlike biodiesel production through transesterification, HEFA biofuel production requires $\mathrm{H}_{2}$ to hydrotreat the biomass. It is suggested that the capital cost for HEFA is $20 \%$ higher than that of biodiesel production due to the hydrotreating process [59] if compared with the transesterification process. However, the co-products from HEFA - naphtha, liquefied petroleum gas (LPG), propane, and diesel-have more credits [59]. The hydrocarbon products from the hydroisomerization/cracking reactor are sent to the first distillation column to remove gaseous products. The gaseous products, which contain propane, $\mathrm{H}_{2}, \mathrm{CO}_{2}$, and trace amounts of liquid hydrocarbons, are subjected to further separation. In the propane purification unit, the propane is dissolved in hexane and separated from $\mathrm{CO}_{2}$ and $\mathrm{H}_{2}$. Propane is conserved and can be sold as a co-product. $\mathrm{CO}_{2}$ and $\mathrm{H}_{2}$ are vented or recycled. Propane is either created by breaking the carbon backbone of the triglyceride or formed in the fractionation step. In 2015, the wholesale propane price ranged from $\$ 0.4$ to $\$ 0.8 /$ gal [60].

The liquid products containing all the hydrocarbons are sent to a distillation column. The $\mathrm{C}_{6}-\mathrm{C}_{8}$ hydrocarbons are distillated to the top and the $\mathrm{C}_{9}-\mathrm{C}_{18}$ products are left at the bottom $[49,50,56]$ in the second distillation column, where naphtha is purified to the overhead of the column. The naphtha product will be sold as gasoline surrogate. The price of naphtha is $\$ 2.0 /$ gal in 2010 US dollars for a 5-year average [24]. The heavier species in the second columns are further separated in the third distillation column. Heavier compounds like $\mathrm{C}_{17}$ and $\mathrm{C}_{18}$ hydrocarbons that stayed at the bottom are considered diesel alternatives $[49,50]$. The overhead stream with hydrocarbons ranging from $\mathrm{C}_{8}$ to $\mathrm{C}_{16}$ is considered jet fuel range blendstocks. Residual unconverted oil is considered as impurities and a disposal fee would be applied to dispose of the residue stream. Diesel is separated in the fractionation step. The current national average price of biodiesel (B20) is around \$2.9/gal and \$3.6/gal for biodiesel (B99/B100) [61].

\section{Outside battery limits units}

All of the wastewater generated in the conversion process is sent to a wastewater treatment (WWT) system, using similar design and cost assumptions as documented in other recent TEA reports [62]. Although this is a costly 
operation, it yields clean and fully reusable water, which reduces both the fresh makeup water demand and discharge to the environment. All residual oil and unconverted carbon, plus WWT biogas, sludge, and other gas streams, are combusted in an on-site boiler/steam turbine system to produce steam and electricity, which are used to help meet the facility's energy demands. The costing basis for the boiler/steam turbine and all other utility operations is also maintained consistently with prior recent design cases [62,63]. The storage area includes storage tanks for propane, hydrocarbon fuels, and water. Water and energy are also integrated for each process.

\section{Aspen model and techno-economic analysis}

The National Renewable Energy Laboratory (NREL) develops and maintains TEA models that describe the process and production economics of conceptual biochemical conversion pathways to biofuels and bioproducts. For a given set of conversion parameters, material and energy balance and flow rate information are generated using Aspen Plus process simulation software [64], assuming a feed rate to the biorefinery of 788 dry US tons of oil per day. These data are used to size and cost process equipment and compute raw material and other operating costs. Using a discounted cash flow rate of return analysis, the minimum jet fuels selling price (MJSP) required to obtain a net present value of zero for a $10 \%$ internal rate of return is determined. The result is a TEA model that reasonably estimates an " $n$ thplant" production cost for this pre-commercial process. Table 2 summarizes the financial assumptions applied in this study.

The economic analysis includes a conceptual process design that leads to the development of a detailed process flow diagram (based on research or commercial data); rigorous material and energy balance calculations (via a commercial simulation tool, Aspen Plus); capital and project cost estimations (via an in-house model using spreadsheets); a discounted cash flow economic model; and the calculation of a minimum fuel selling price [62, 65, 66] or MJSP. The operating expense calculation for the designed facility is based on material and energy balance calculations using Aspen Plus process simulations [64]. All costs are adjusted to 2014 US dollars (2014\$) using the Plant Cost Index from Chemical Engineering Magazine [67], the Industrial Inorganic Chemical Index from SRI Consulting [68], and the labor indices provided by the US Department of Labor Bureau of Labor Statistics [69].

Raw materials include feedstocks (lipid or oil biomass) and chemicals (boiler chemicals, cooling tower chemicals, and makeup amine for the gas cleanup), and upgrading chemicals (catalysts and $\mathrm{H}_{2}$ ) with detailed cost information listed in previous reports and peer-reviewed papers. The feedstock cost varies from $\$ 0.40$ to $\$ 1.75 /$ $\mathrm{kg} 2014 \$$ depending on the feedstock type shown in Table 3, and the overall process efficiency (or on-stream factor) is assumed to be $90 \%$ (7884 operating hours per year), consistent with other TEA design reports [70, 71]. The operating expense calculation for the designed facility is based on material and energy balance calculations using Aspen Plus process simulations [64]. All costs are inflated to 2014\$ using the Plant Cost Index from Chemical Engineering Magazine [72], the Industrial Inorganic Chemical Index from SRI Consulting [73], and the labor indices provided by the US Department of Labor Bureau of Labor Statistics [74]. Salaries for personnel are inflated to $2014 \$$ [74]. Sixty percent of the total salaries are added

Table 2 nth-plant assumptions for TEA $[49,50]$

\begin{tabular}{|c|c|}
\hline Economic parameters & Assumed basis \\
\hline Basis year for analysis & 2014 \\
\hline Debt/equity for plant financing & $60 \% / 40 \%$ \\
\hline Interest rate and term for debt financing & $8 \%$ annually/ 10 years \\
\hline Internal rate of return for equity financing & $10 \%$ \\
\hline Total income tax rate & $35 \%$ \\
\hline Plant life & 30 years \\
\hline Plant depreciation schedule & 7 years \\
\hline Plant salvage value & 0 \\
\hline Construction period & 3 years \\
\hline Fixed capital expenditure schedule & $\begin{array}{l}8 \% \text { in year } 1,60 \% \text { in } \\
\text { year } 2 \text { and } 32 \% \text { in } \\
\text { year } 3\end{array}$ \\
\hline Start-up time & 0.5 year \\
\hline Revenues during startup & $50 \%$ \\
\hline Variable costs during startup & $75 \%$ \\
\hline Fixed costs during startup & $100 \%$ \\
\hline On-stream percentage after startup & $90 \%$ \\
\hline Site development costs & $\begin{array}{l}9 \% \text { of ISBL, total } \\
\text { installed cost }\end{array}$ \\
\hline Warehouse & $4 \%$ of ISBL \\
\hline Working capital & $\begin{array}{l}\text { 5\% of fixed capital } \\
\text { investment }\end{array}$ \\
\hline Indirect costs & $\%$ of total direct costs \\
\hline Prorated expenses & 10 \\
\hline Home office and construction fees & 20 \\
\hline Field expenses & 10 \\
\hline Project contingency & 10 \\
\hline Other costs (startup and permitting) & 10 \\
\hline Fixed operating costs & Assumed basis \\
\hline Total salaries & 60 employees \\
\hline Benefits and general overhead & $90 \%$ of total salaries \\
\hline Maintenance & $3 \%$ of ISBL \\
\hline Insurance and taxes & $\begin{array}{l}0.7 \% \text { of fixed capital } \\
\text { investment }\end{array}$ \\
\hline
\end{tabular}

ISBL inside battery limits (of the plant) 
Table 3 Oil price [95-103], product yield for a biorefinery with 788 dry ton oil per day

\begin{tabular}{lccccc}
\hline & Jatropha & Camelina & Pennycress & Castor & Yellow grease \\
\hline Oil price $(\$ / \mathrm{kg})$ & $\$ 0.40$ & $\$ 1.75$ & $\$ 0.81$ & $\$ 1.70$ & $\$ 0.61$ \\
Jet fuel production (MMgal/year) & 44.0 & 57.7 & 40.3 & 50.8 & 1.8 \\
Propane fuel yield (gal/dry ton oil) & 18.3 & 1.0 & 7.1 & 94.4 & 1.6 \\
Gasoline fuel yield (gal/dry ton oil) & 94.2 & 100.0 & 155.5 & 196.2 & 194.7 \\
Jet fuel yield (gal/dry ton oil) & 170.0 & 184.3 & 36.9 & 0.5 & 0.8 \\
Diesel yield (gal/dry ton oil) & 3.1 & 4.7 & & \\
\hline
\end{tabular}

for labor burden, and $2.0 \%$ of the total installed capital is designated for maintenance (which includes expenses on cleaning) [26]. Property insurance and taxes account for $1.5 \%$ of the total capital investment [26]. The federal corporate tax rate used in our analysis is $35 \%$ in US. Income tax is averaged over the plant life and that average is calculated on a per-gallon basis. The amount of income tax to be paid by a potential fuel producer varies annually due to changes in the volume of product produced and the allowable depreciation deduction (Additional file 1).

After the total capital investment, variable operating costs, and fixed operating costs are determined, a discounted cash flow rate of return analysis is typically used to determine the minimum fuel selling price (such as MJSP). The discounted cash flow analysis is calculated by iterating the selling cost of the product until the net present value of the project is zero with a $10 \%$ internal rate of return. The analysis requires that the discount rate, depreciation method, income tax rates, plant life, and construction start-up duration be specified. The discounted cash flow assumes $40 \%$ equity financing with a loan interest at $8 \%$ for 10 years. Working capital is assumed to be $5 \%$ of the fixed capital investment. The plant is assumed to take 3 years to construct with a half of a year spent on startup. The Internal Revenue Service Modified Accelerated Cost Recovery System (MACRS) was used because it offered the shortest recovery period and largest tax deductions, consistent with several NREL design reports $[62,63,70,75]$, in which the steam production plants depreciates in a 20 -year recovery period and all other properties depreciate in a 7 -year recovery period. The plant's life is assumed to be 30 years. The detailed method is described in the previous published NREL design reports $[62,63,75]$.

It should be emphasized that our analyses and the resultant MJSP values carry some uncertainty related to the assumptions made about capital and raw material costs. Without a detailed understanding of the basis behind it, the absolute computed cost values have limited relevance. Cost values are therefore best used to compare technological variations or process improvements against one another. By demonstrating the cost impact of various process parameters individually or in concert, the model helps guide research by indicating where the largest opportunities for cost reduction exist.

\section{Results \\ Feedstock analysis}

It is estimated that about 16 million tonnes of vegetable oils, animal fats, and greases are produced annually in the US [76]. About $67 \%$ of this amount comes from domestic oil crops, $28 \%$ from animal fats and greases, and the remaining from other sources such as tall oil. A variety of oil crops are grown in the US, including soybean, peanut, sunflower, canola, and flax. Production is concentrated in the Corn Belt and along the Mississippi River (Fig. 2). Soybeans are the dominant oilseed in the US, accounting for about $90 \%$ of US oilseed production while other oilseeds make up the remainder [77]. The US imports palm, palm kernel, and coconut oil, which are primarily used in the food and chemical industries.

Figure 3 illustrates the yield of major oil crops and prices of vegetable oils, animal fats, and greases. Oil crops currently grown in the US (namely soybean) have relatively low oil yield when compared to oil crops grown in other, mainly tropical, parts of the world (e.g., palm, coconut, and jatropha). Algae are expected to have high productivity, which is yet to be proven at commercial scale, but model-derived estimates indicate a prohibitively high price as a biofuel feedstock $[29,78]$. Similarly, imported tung oil has a high price and is unlikely to be used as biofuel feedstock.

Castor and pennycress are promising feedstocks for biofuels production given their relatively high yield and because they are non-food oil sources. However, because of its ricinoleic acid content, castor oil is a valuable feedstock for the chemical industry and thus may maintain a higher price than other seed oils even if produced domestically. Castor bean can be grown in the US, as it was in the past and there is revived interest in bringing it back. It, however, would require strong regulations. Canola oil is viewed favorably given its higher-than-soybean yield and is already in use as a biofuels feedstock (for biodiesel production). Lately, however, its use as a 


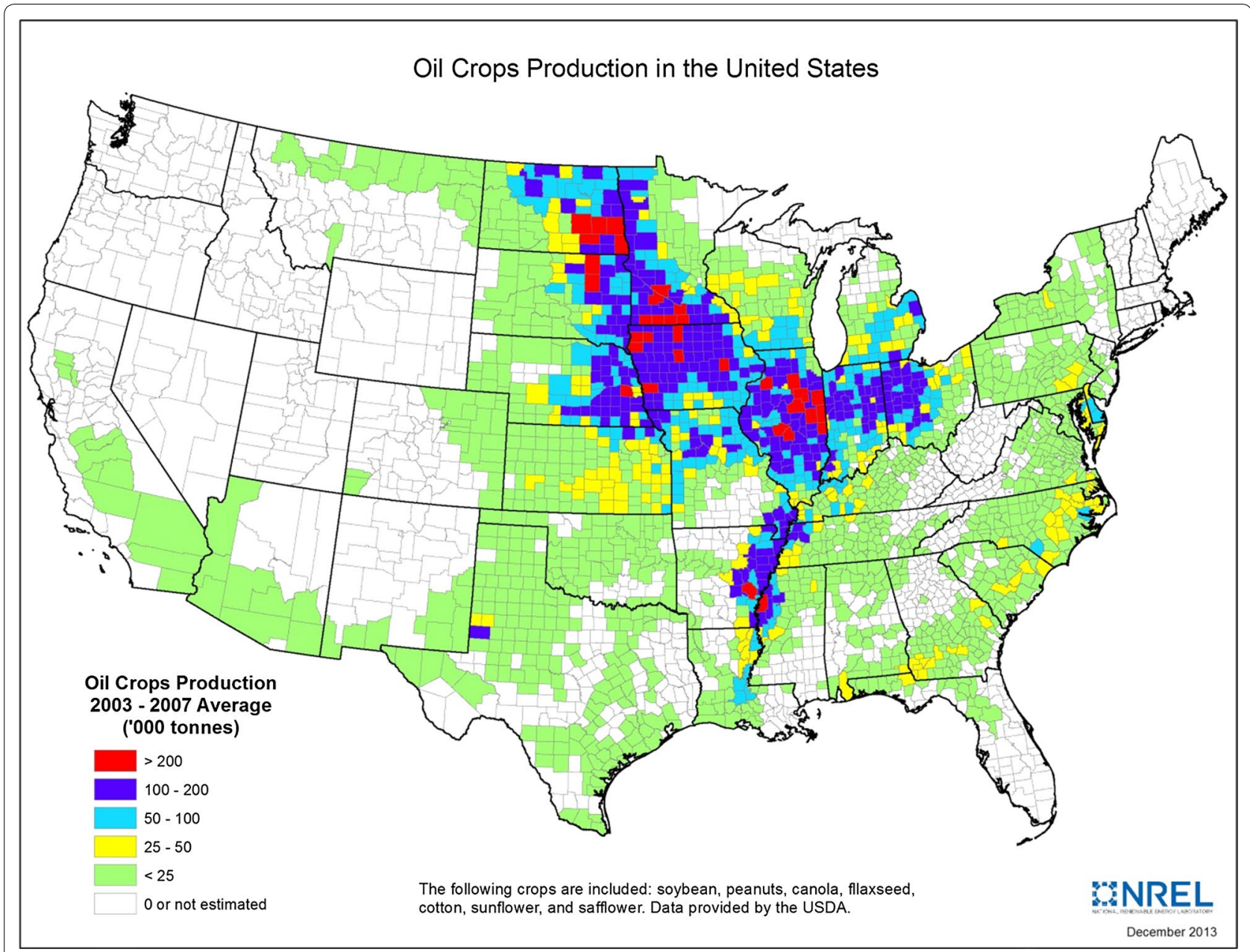

Fig. 2 Oil crops production in the US (2003-2007 average)

biofuels feedstock is facing competition from the food industry, which uses it as a partial replacement for soybean oil and that may lead to prices much higher than other seed oils. Peanut oil also has a higher-than-soybean yield and is more valuable in the market than soybean oil, which makes its use for biofuels production economically impractical. Figure 3 also illustrates that non-terrestrial oil sources such as animal fats and greases have relatively lower prices than terrestrial oil crops. Lower prices and availability has led to increased use of these resources for biofuels production such as biodiesel and renewable diesel in recent years.

\section{Feedstock fatty acid profile}

To support our analysis, we collected and analyzed the FFA profile for 24 oil feedstocks. When defining the oil feed, it is assumed that triglycerides, diglyceride and mono-glycerides are main constituents of the bio-oils. For example, in jatropha oil, the compositions of tri-, di-, and mono-glycerides and FFA are 80.4, 2.1, 2.5, and $15.0 \%$, respectively [79]. There are many different types of tri-, di- and mono-glyceride, with the main division between saturated and unsaturated types. The fatty acid compositions are presenting in the form of triglycerides with glycerol in the backbones, also illustrated by Eqs. 49. For example, $1 \mathrm{~mol}$ triolein is formed by $3 \mathrm{~mol}$ of oleic acid. The structure of each of the three fatty acids within a single triglyceride often varies, so the resulted fatty acid profile varies, as listed in Fig. 4 [80-87]. The fatty acids distribute from 8 carbons to 24 carbons. Most oils contain mainly $\mathrm{C}_{16}$ and $\mathrm{C}_{18}$ FFA. The exceptions are for pennycress, yellow grease, tallow, mustard, and coconut oil.

Oil feedstocks with significant amounts of $\mathrm{C}_{20}$ will need hydrocracking (e.g. mustard). Oils with smaller carbon ranges (e.g. coconut oil) would be better candidates for gasoline production. For instance, pennycress has a significant percentage of $\mathrm{C}_{20}$. Hydrocracking might be needed for improved jet production. Yellow grease has a 


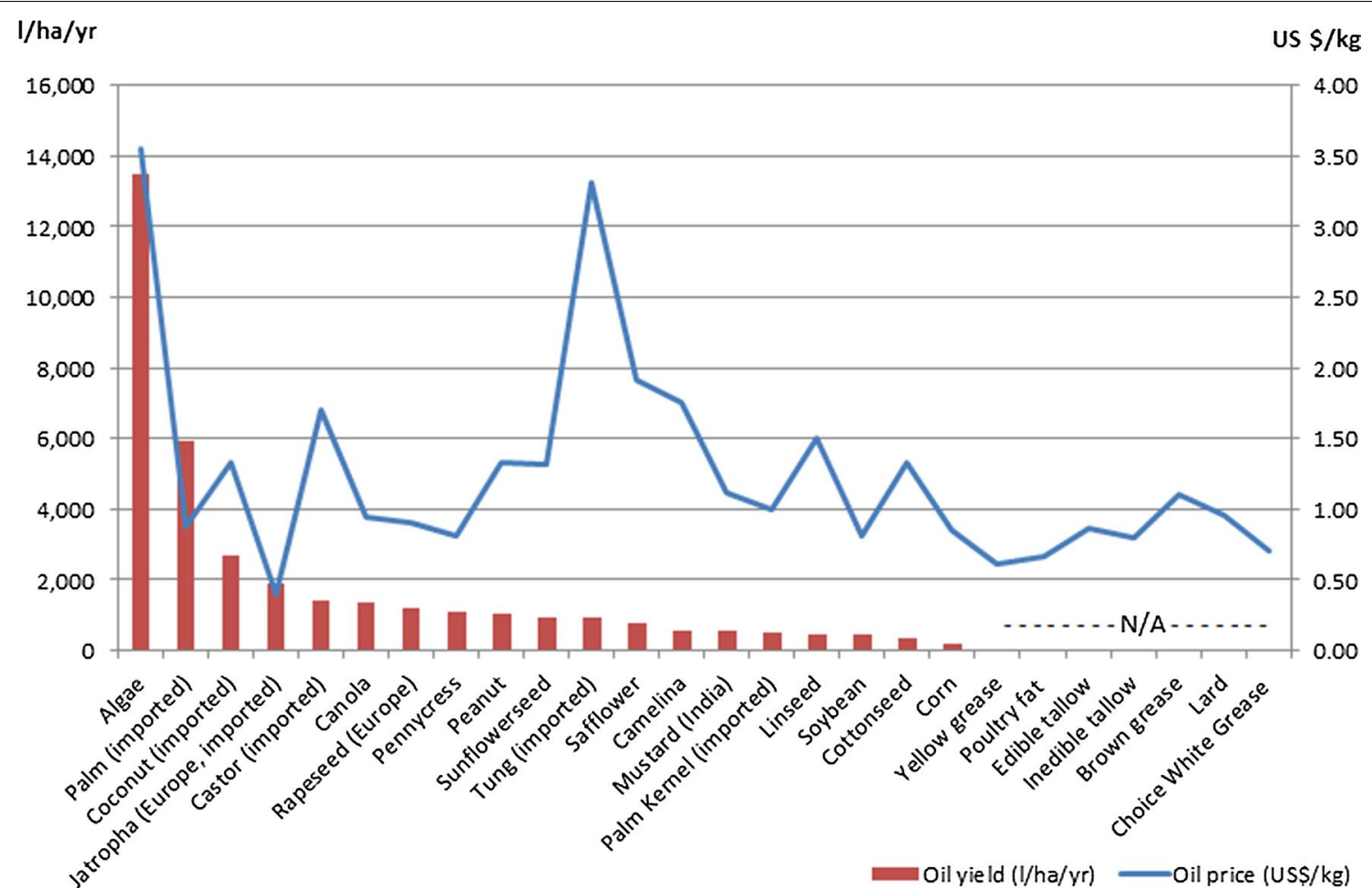

Fig. 3 Oil yield and prices. Prices are for local, US feedstock unless otherwise noted. Prices are for 2014, except linseed oil (latest data available from the USDA is for 2010); brown grease (undisclosed time in 2011); safflower and jatropha (2013/2014); mustard (2015); and camelina and algae (model-derived estimates)

small but non-negligible percentage of both $\mathrm{C}_{14}$ and $\mathrm{C}_{20}$. Hydrocracking will be required for jet production. Wider distribution of carbon numbers would be expected for the resulting hydrocarbon fuels. Edible tallow has a small percentage of $\mathrm{C}_{14}$. Mustard has almost $30 \%$ of $\mathrm{C}_{20}$ and hydrocracking will be required for jet production. Coconut oil has a much wider range of carbons than most other oils with the carbon number ranges from $\mathrm{C}_{8}$ to $\mathrm{C}_{16}$. The content of $\mathrm{C}_{16}$ in coconut oil is only $8 \%$, making it a feedstock candidate for gasoline production, instead of for jet or diesel production.

\section{TEA results for select feedstocks}

In jatropha oil, the compositions of tri-, di-, and monoglycerides and FFA are 80.4, 2.1, 2.5 and 15.0\%, respectively [79], with corresponding FFAs shown in Fig. 4. The majority of extracted FFA in jatropha is $\mathrm{C}_{18}$. The hydrogenation steps for both saturated and unsaturated triglycerides are critical for upgrading jatropha oil, due to the high content of triglycerides. The high triglycerides content also results in a high yield of propane, as illustrated in Fig. 5. The resulting FFAs, however, are mostly in the range of $\mathrm{C}_{8}-\mathrm{C}_{18}$, so hydrocracking mainly cracks $\mathrm{C}_{15}$ and $\mathrm{C}_{17}$. The final product and co-products, including jet, diesel, naphtha, and propane, are illustrated in Fig. 5.
The HEFA using jatropha oil produces 32\% naphtha, $62 \%$ jet, $1 \%$ diesel, and $5 \%$ propane. With feedstock throughput of 788 dry tons oil per day, the production rate of each product and co-product are summarized in Table 3. Hydrocracking is applied whenever possible to maximize jet hydrocarbon productions.

Camelina has a typical oil content of $40 \%$ and can produce higher amounts of $\alpha$-linolenic acid. Camelina (false flax) oil is an important source of linolenic acid $\left(\mathrm{C}_{18: 3}\right)$ [88]. We have assumed $100 \%$ FFA for camelina oil in the TEA, so the first hydrogenation step is almost bypassed with low production of propane. Similar to jatropha, the FFAs are mostly in the range of $\mathrm{C}_{8}-\mathrm{C}_{18}$, so hydrocracking mainly cracks $\mathrm{C}_{15}$ and $\mathrm{C}_{17}$. Production yields are summarized in Table 3.

The oil content of dried field pennycress seeds is 29.0 $\mathrm{wt} \%$. The primary FFA in pennycress is erucic acid (32.8 wt\% of $\mathrm{C}_{22: 1}$ ), which is typical among members of the Brassicaceae family [34]. With significant amounts of $\mathrm{C}_{20}$ and $\mathrm{C}_{22}$ in the pennycress oil, the hydrocracking mainly cracks $\mathrm{C}_{15+}$. Because pennycress has a significant percentage of $\mathrm{C}_{20+}$, even with a hydrocracker, the diesel yield (shown in Fig. 5 and Table 3), is still significantly higher than that from the other oils. Malaysian castor seeds contain a relatively high percentage of oil, and total lipids 


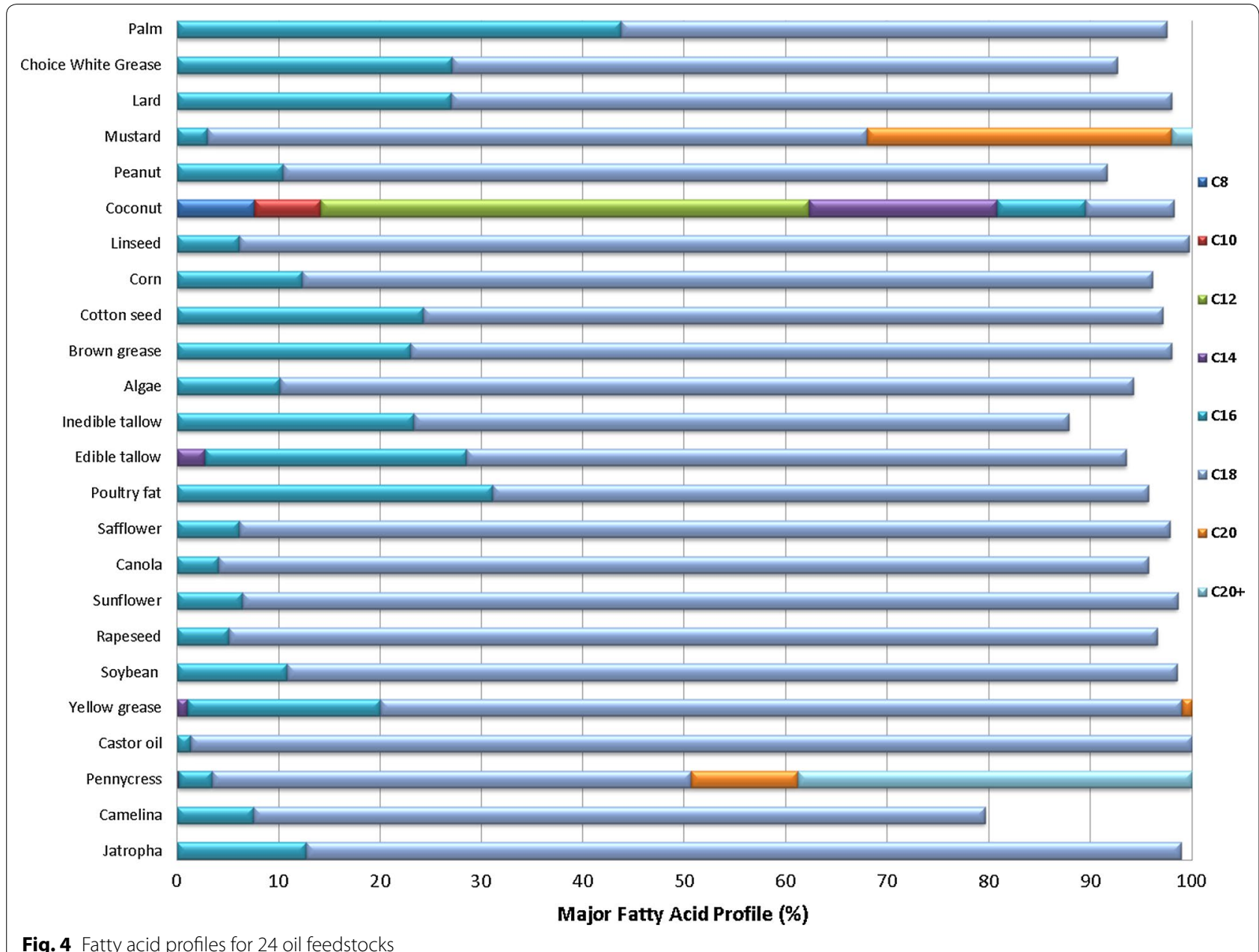

content is $43.3 \%$ (per dry weight) [89]. The unsaturated fatty acids content was $97.5 \%$ of the total fatty acids composition. Oil feedstocks with unsaturated fatty acid contents typically require higher amount $\mathrm{H}_{2}$ to remove the $\mathrm{OH}$ groups. Ricinoleic acid comprises over $84 \%$ while other fatty acids present are linoleic (7.3\%), oleic (5.5\%), palmitic (1.3\%), stearic (1.2\%), and linolenic (0.5\%) [89] (Fig. 4). Similar to jatropha, the FFAs are mostly in the range of $\mathrm{C}_{8}-\mathrm{C}_{18}$, so hydrocracking mainly cracks $\mathrm{C}_{15}$ and $\mathrm{C}_{17}$.

Lower cost feedstocks such as animal fats, yellow grease, and brown grease are high in FFA [90], with the range of $\mathrm{C}_{8}-\mathrm{C}_{18}$. Although yellow grease has a small but non-negligible percentage of both $\mathrm{C}_{14}$ and $\mathrm{C}_{20}$ and wider distribution of carbon numbers, the jet blendstock yield is comparable with other oil feedstocks, such as jatropha, camelina, and castor oil, indicating a great potential of using the low-grade oil as a good feedstock candidate for making hydrocarbon fuels via oil upgrading.
If the oil feedstock is predominately a $\mathrm{C}_{16}-\mathrm{C}_{18}$ oil, the products are mostly diesel fuel range molecules without the hydrocracking step. Thus, with the addition of the hydrocracking step more jet fuel is produced by catalytically cracking diesel range molecules. The product profile is illustrated in Fig. 5, showing results of the distribution of propane, naphtha, jet, diesel and heave residuals from the five selected oil feedstocks after catalytic oil upgrading and fractionation unit operations. In addition, Table 3 shows the mass-based product yields. In summary, jet fuel ranges from 60 to $70 \%$ for the selected five oil feedstocks. When compared with the data from literature [24], the yields of propane and naphtha are similar. Propane accounts for $2-4 \%$ in weight of all the products, strongly correlated with the tri-, di- and mono-glycerides contents in the oil feedstocks. In our case, more hydrocarbons are distributed in the jet fuel pool because cracking reactions are assumed in the hydrocracker. Moreover, more $\mathrm{CO}_{2}$ is presented because only decarboxylation 


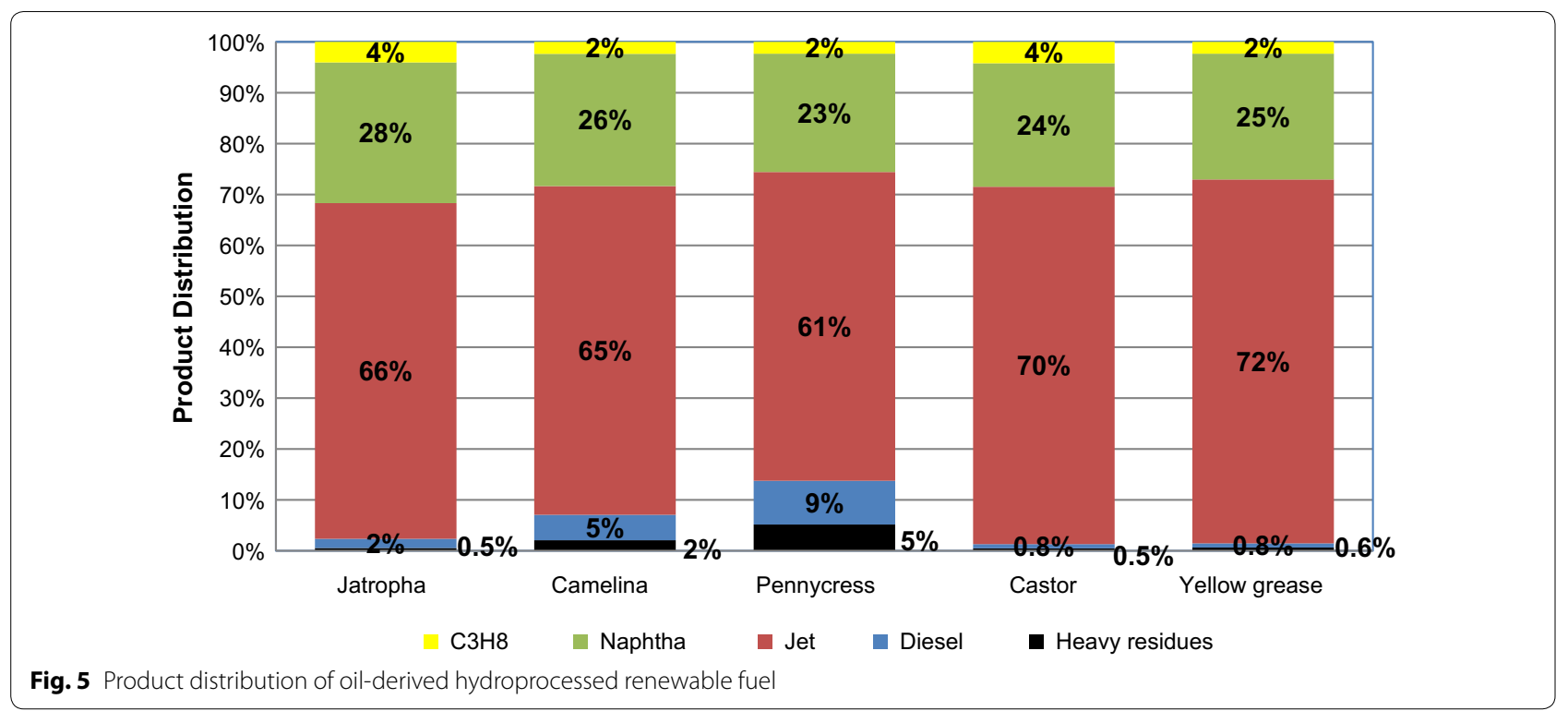

is represented for the deoxygenation process if compared with that in the study done by Pearlson et al. [24] in which both decarboxylation and hydrodeoxygenation are assumed. Product yields and distribution are generally consistent with data from the published TEA using soybean oil as the feedstock [24]. The estimated MJSP is shown in Fig. 6, including feedstock, other operating cost (OPEX) and capital contributions.

In this study, both camelina and castor bean prices are high, resulting in over $80 \%$ cost contribution from feedstock costs (see Table 3). The feedstock contribution for the other oils range from 55 to $69 \%$. Similar to the literature, $76-88 \%$ of the total production cost is contributed by the cost of feedstocks [91-94]. Capital investment is similar for all five processes with selected feedstocks, ranging from $\$ 341$ to $\$ 354$ million for total capital investment and contributing $10-25 \%$ of overall jet production cost. Total capital cost includes the capital depreciation and return on capital. Cost contribution from other OPEX has $\mathrm{H}_{2}$ consumption in the oil upgrading steps, catalysts costs, and additional utility costs. Utilities must be purchased for the HEFA facilities unless there is an on-site boiler and combined heat and power. The MJSPs shown in Fig. 6 are calculated based on jet

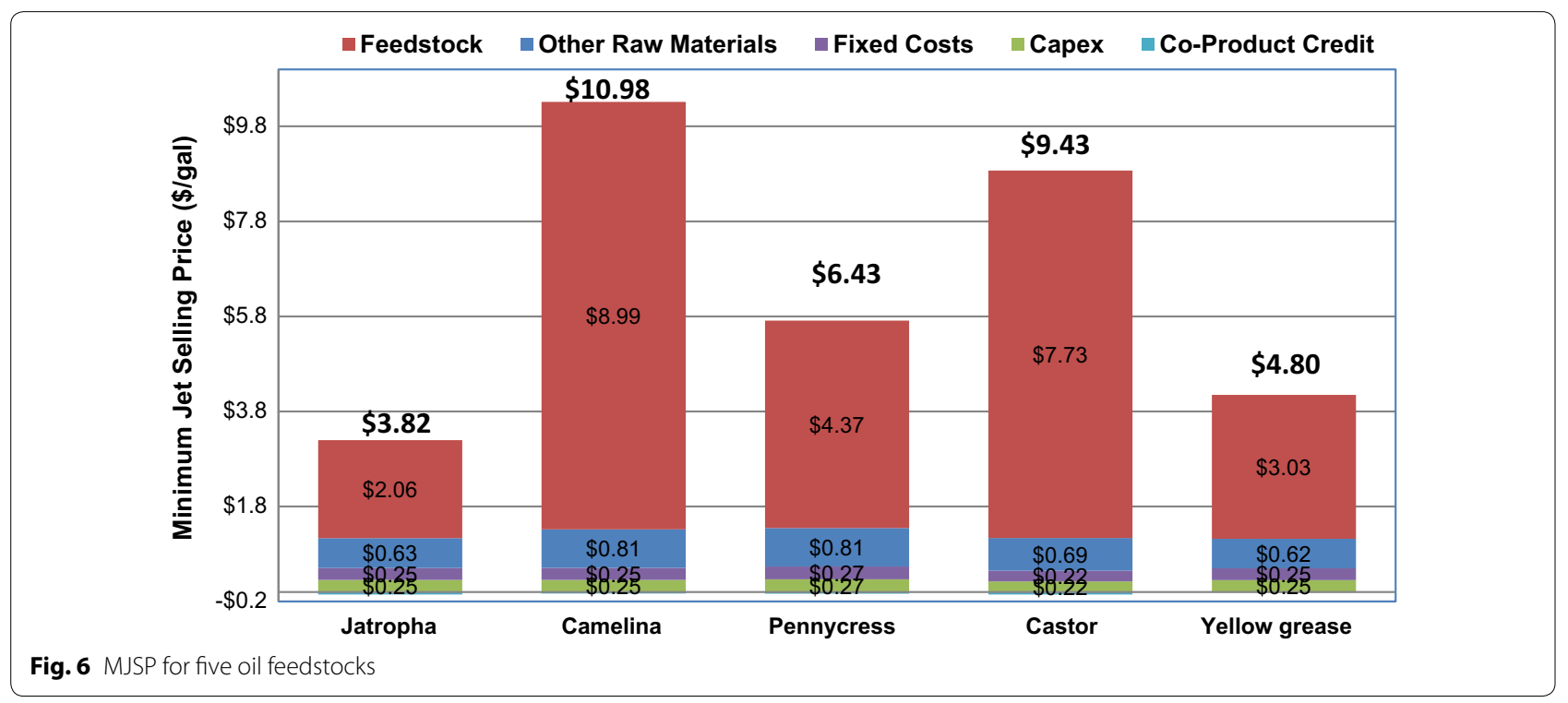


blendstocks as the main products, while selling propane, diesel, and gasoline blendstocks as co-products. The MJSP ranges from $\$ 3.8$ to $\$ 11.0 /$ gal jet. The big variations of MJSP for the selected five oil feedstocks are mainly due to differences in oil prices. Variations on capital costs are relatively small.

A single-point sensitivity analysis is performed on the HEFA process using jatropha oil. Minima and maxima for each variable are chosen to understand and quantify the resulting cost impact on overall MJSP. Each variable is changed to its minimum and maximum value with all other factors held constant. Most correlations are linear, except the correlation between plant scale and MJSP. The results and limits are shown in Fig. 7. The oil price, plant capacity, total capital investment, oil upgrading catalyst loadings, process efficiency and catalyst prices, and total capital investment have the largest impact on MJSP. Therefore, they are key cost drivers. The feedstock (oil) price, catalysts loadings and prices, and $\mathrm{H}_{2}$ price are positively correlated to MJSP. Plant scale, process efficiency and jet fuel yields also have a strong impact on MJSP, but they are negatively correlated. The other parameters chosen for this study (such as isomerization and hydrocracking catalyst price) show minimal contribution to MJSP. It is noted that pathways from different oil feedstocks follow similar patterns for this sensitivity study. Beside the other variables mentioned as the largest cost drivers, new developments in reactor type (for hydrotreating, propane cleave, or for hydrocracking and hydroisomerization) could reduce the MJSP significantly.

\section{Conclusions}

The resource analysis indicates that oil crops currently grown in the US (such as soybean) have relatively low oil yield when compared to oil crops grown in other, mainly tropical, parts of the world (e.g., palm, coconut, and jatropha). Higher-yielding oil crops such as canola and camelina are increasingly grown in the country but they are facing competition with the food industry; thus it is unclear what the future holds for these resources. While receiving a lot of attention, pennycress and jatropha are slow to develop for various reasons (e.g., agronomic, economic, and social). Non-terrestrial oil sources such as animal fats and greases have relatively lower prices than terrestrial oil crops and thus are increasingly used for biofuels production. With inputs from resource analysis on feedstock compositions profiles, oil prices, and availability, TEA is performed for five selected oil feedstocks using the HEFA process concept. The five selected oils are camelina, pennycress, jatropha, castor bean, and yellow grease. Please note that there are no mature feedstock markets at the moment available for the four

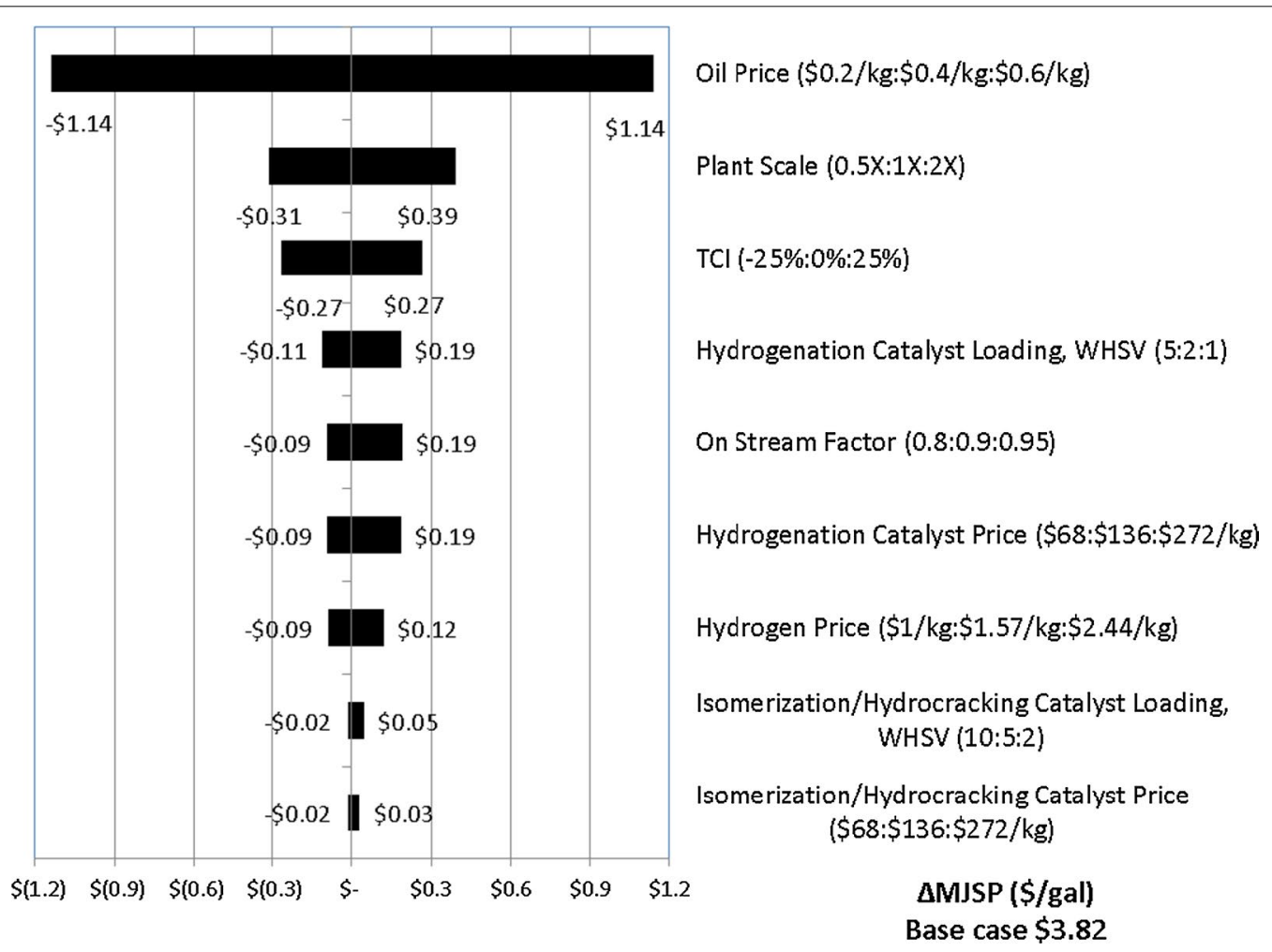

Fig. 7 Single point sensitivity for MJSP of jatropha oil 
oilseeds analyzed, and the feedstock prices are still quite volatile in the current market. For instance, the MJSP for these five resources ranges between $\$ 3.8$ and $\$ 11.0$ per gallon jet blendstocks, mainly due the variation of oil feedstock prices. If feedstock price can be assumed the same, the MJSP variation is small. Feedstock is the main component of MJSP for HEFA. Jet fuel generally comprises around $60 \%$ of output for the oil feedstocks studied in this work. Sensitivity analysis indicates that the key cost drivers are feedstock price, conversion plant capacity, fatty acid profile, addition of hydrocracker, and type of hydroprocessing catalysts. Both edible and nonedible oils are promising alternative fuel feedstocks not only because they are renewable and can be produced locally and in environmentally friendly ways, but also because they can be cost competitive with strategic process design and integration, taking into consideration oil prices, resources, and feedstock composition profiles. Because there are currently no mature feedstock markets available for the four oilseeds analyzed, uncertainty analysis will be conducted in the future.

\section{Additional file}

Additional file 1. Additional Explanation on the Terminologies.

\section{Abbreviations}

AJF: alternative jet fuel; HEFA: hydroprocessed esters and fatty acids; ASTM: American Society for Testing and Materials; ElA: Energy Information Administration; FFA: free fatty acid; GHG: greenhouse gas; HFA: hydroxylated fatty acids; HRJ: hydroprocessed renewable jet; ISBL: inside battery limits (of the plant); LPG: liquefied petroleum gas; MJSP: minimum jet fuel selling price; TEA: techno-economic analysis; SPK: synthetic paraffinic kerosene; USDA: US Department of Agriculture; WWT: wastewater treatment.

\section{Authors' contributions}

LT participated in study design, collected and processed the data, conducted techno-economic analysis of oil-to-jet pathways, analyzed the results, and drafted the manuscript. AM collected resource data, performed the resource analysis analyzed the results, and drafted the manuscript. YZ and WW conducted techno-economic analysis of oil-to-jet pathways. All authors read and approved the final manuscript.

\section{Acknowledgements}

Special thanks to the Economic Research Service staff at the USDA, The Trade News Service, Oilseeds International Ltd., and the National Renderers Association for providing price data for most oil feedstocks. We also thank Mary Biddy and Emily Newes for critical readings of the manuscript, and Billie J. Christen for editing the manuscript.

\section{Competing interests}

The authors declare that they have no competing interests.

\section{Availability of supporting data}

Available upon request.

\section{Consent for publication}

Not applicable.
Ethics approval and consent to participate Not applicable.

\section{Funding}

This study was supported by the Biomass Energy Technology Office in the US Department of Energy's Office of Energy Efficiency and Renewable Energy.

\section{Publisher's Note}

Springer Nature remains neutral with regard to jurisdictional claims in published maps and institutional affiliations.

Received: 4 January 2017 Accepted: 24 October 2017

Published online: 09 November 2017

\section{References}

1. What fuels are made from crude oil? http://www.eia.gov/energyexplained/index.cfm?page=oil_refining.

2. Air Transportation Action Group. Beginner's guide to aviation biofuels. 2nd ed. Geneva: Air Transportation Action Group; 2011.

3. Stratton RW, Wong HM, Hileman JI. Life cycle greenhouse gas emissions from alternative jet fuels. Cambridge: PARTNER (Partnership for Air Transportation Noise and Emissions Reduction); 2010.

4. Jet fuel consumption, price, and expenditure estimates, 2015. http:// www.eia.gov/state/seds/data.cfm?incfile=/state/seds/sep_fuel/html/ fuel_jf.html.

5. Holland A, Cunningham N. DoD's biofuels program. Washington, DC: American Security Project; 2013

6. Blakeley K. DOD alternative fuels: policy, initiatives and legislative activity. Washington: Congressional Research Service; 2012.

7. Lane J. US Navy, DOE, USDA award $\$ 210 \mathrm{M}$ for 3 biorefineries and milspec fuels. Key Biscayne: Biofuels Digest; 2014.

8. Wang WC, Tao L, Markham J, Zhang Y, Tan E, Batan L, Warner E, Biddy M. Review of biojet fuel conversion technologies. Golden: NREL (National Renewable Energy Laboratory); 2016.

9. ASTM D975-12a standard specification for diesel fuel oils. http://www. astm.org/Standards/D975.htm.

10. Pearlson MN. A techno-economic and environmental assessment of hydroprocessed renewable distillate fuels. Cambridge: Massachusetts Institute of Technology Technology and Policy; 2007.

11. Atlantic V. Virgin Atlantic becomes world's first airline to fly a plane on biofuel. Crawley: Virgin Atlantic; 2008.

12. Green Air. Japan Airlines demonstration flight concludes current series of alternative biofuel feedstocks testing. Luxembourg: Green Air; 2009.

13. Green Air. TAM Airlines conducts first-ever Airbus biofuel flight using Brazilian-sourced jatropha-based kerosene blend. Luxembourg: Green Air; 2010.

14. Green Air. China joins the sustainable jet biofuel flight club as Air China and Boeing conduct two-hour demonstration. Luxembourg: Green Air; 2011.

15. Honeywell. Honeywell Green Jet Fuel ${ }^{\mathrm{TM}}$ powers gulfstream flights to NBAA. Morris Plains: Honeywell; 2012.

16. Green Air. Etihad becomes first Middle East carrier to use sustainable biofuel as it takes delivery of new Boeing aircraft. Luxembourg: Green Air; 2012.

17. Kessler RA. US Air Force A-10 aircraft biofuel flight test a success. Recharge news. 2010. http://www.rechargenews.com/news/ biofuels/860379/us-air-force-a-10-aircraft-biofuel-flight-test-a-success.

18. Air Green. Colombia's first commercial biofuel flight uses camelinabased renewable jet fuel blend from Honeywell. Luxembourg: Green Air; 2013.

19. Air Green. Canadian researchers to carry out first-ever civil aircraft test flight to use 100 per cent jet biofuel. Luxembourg: Green Air; 2012.

20. Who we are: our roots. https://www.neste.com/en/corporate-info/ who-we-are/our-roots.

21. Honeywell Green Jet Fuel. https://www.uop.com/processing-solutions/ renewables/green-jet-fuel/. 
22. Bann SJ, Malina R, Staples MD, Suresh P, Pearlson M, Tyner WE, Hileman $\mathrm{Jl}$, Barrett $\mathrm{S}$. The costs of production of alternative jet fuel: a harmonized stochastic assessment. Biores Technol. 2017;227:179-87.

23. Seber G, Malina R, Pearlson MN, Olcay H, Hileman Jl, Barrett SRH. Environmental and economic assessment of producing hydroprocessed jet and diesel fuel from waste oils and tallow. Biomass Bioenerg. 2014;67:108-18.

24. Pearlson M, Wollersheim C, Hileman J. A techno-economic review of hydroprocessed renewable esters and fatty acids for jet fuel production. Biofuels Bioprod Biorefin. 2013;7:89-96.

25. Davis R, Aden A, Pienkos PT. Techno-economic analysis of autotrophic microalgae for fuel production. Appl Energy. 2011;88:3524-31.

26. Davis R, Fishman D, Frank ED, Wigmosta MS, Aden A, Coleman AM, Pienkos PT, Skaggs RJ, Venteris ER, Wang MQ. Renewable Diesel from Algal Lipids: An Integrated Baseline for Cost, Emissions, and Resource Potential from a Harmonized Model. Golden: National Renewable Energy Laboratory (NREL); 2012.

27. Davis R, Kinchin C, Markham J, Tan E, Laurens LML, Sexton D, Knorr D, Schoen P, Lukas J. Process design and economics for the conversion of algal biomass to biofuels: algal biomass fractionation to lipid- and carbohydrate-derived fuel products 2014. https://www.nrel.gov/docs/ fy140sti/62368.pdf.

28. Davis R, Fishman D, Frank ED, Wigmosta MS, Aden A, Coleman AM, Pienkos PT, Skaggs RJ, Venteris ER, Wang MQ. Renewable diesel from algal lipids: an integrated baseline for cost, emissions, and resource potential from a Harmonized Model. 2012. Golden, CO: National Renewable Energy Laboratory; 2012. http://www.nrel.gov/docs/fy12osti/55431.pdf.

29. Davis R, Markham J, Kinchin C, Grundl N, Tan E, Humbird D. Process design and economics for the production of algal biomass: algal biomass production in open pond systems and processing through dewatering for downstream conversion. Golden: National Renewable Energy Laboratory; 2016.

30. Quinn JC, Davis R. The potentials and challenges of algae based biofuels: a review of the techno-economic, life cycle, and resource assessment modeling. Biores Technol. 2015;184:444-52.

31. Wigmosta MS, Coleman AM, Skaggs RJ, Huesemann MH, Lane LJ. National microalgae biofuel production potential and resource demand. Water Resour Res. 2011;47(3):W00H04. doi:https://doi. org/10.1029/2010WR009966.

32. Lafferty RM, Rife C, Foster G. Spring camelina production guide for the Central High Plains. Golden, CO: Blue Sun Agriculture Research \& Development; 2009. p. 14143.

33. Enjalbert J, Johnson J. Guide for producing dryland camelina in eastern Colorado. Adams: Colorado State University Extension; 2011.

34. Moser BR, Knothe G, Vaughn SF, Isbell TA. Production and evaluation of biodiesel from field pennycress (Thlaspi arvense L.) Oilt. Energy Fuels. 2009;23:4149-55.

35. Milbrandt A. Assessment of biomass resources in Liberia. National Renewable Energy Laboratory (NREL) USA. http://www.nrel.gov/docs/ fy09osti/44808.pdf; 2009.

36. Francis $G$, Edinger R, Becker K. A concept for simultaneous wasteland reclamation, fuel production, and socio-economic development in degraded areas in India: need, potential and perspectives of Jatropha plantations. Nat Resour Forum. 2005;29:12-24.

37. Box 11. Jatropha-a "miracle" crop? http://www.greenfacts.org/en/biofuels/figtableboxes/jatropha-crop.htm.

38. Jatropha for biodiesel not a miracle crop. D1 Oils. http://www.reuters com/article/ozabs-safrica-biofuels-jatropha-idAFJOE5300DN20090401.

39. Jatropha curcas. beyond the myth of the miracle crop. http://www. ascension-publishing.com/BIZ/4ABVolckaert.pdf.

40. Woody T. Start-Up Uses Plant Seeds for a Biofuel. New York: The New York Times; 2013.

41. Turner R. Fats and Oils Quality, Characteristics, Extraction and Refining Overview. In: Presentation given at Farm Energy Conference; Manchester, $\mathrm{NH} ; 2010$.

42. Campbell DN, Rowland DL, Schnell RW, Ferrell JA, Wilkie AC. Developing a castor (Ricinus communis L.) production system in Florida, US: evaluating crop phenology and response to management. Ind Crops Prod. 2014;53:217-27.

43. Western Farm Press. Castor an oilseed crop that can cure, kill you. Fresno: Western Farm Press; 2012.
44. Mississippi State University. Toxin-free castor would be major help to industry. Starkville: Mississippi State University; 2010.

45. Biresaw M, Mittal K. Surfactants in tribology. Boca Raton: CRC Press; 2013.

46. El Bassam N. Handbook of bioenergy crops: a complete reference to species, development and applications. Abingdon: Routledge; 2010.

47. Chhikara S, Dutta I, Paulose B, Jaiwal PK, Dhankher OP. Development of an Agrobacterium-mediated stable transformation method for industrial oilseed crop Crambe abyssinica 'BelAnn'. Ind Crops Prod. 2012;37:457-65

48. Bart JC, Palmeri N, Cavallaro S. Biodiesel science and technology: from soil to oil. Amsterdam: Elsevier; 2010.

49. Marker TL, Ellis GD, Gosling CD. Integrated process for oil extraction and production of diesel fuel from biorenewable feedstocks. Washington: United States patent; 2009.

50. Abhari R, Tomlinson L, Havlik P, Jannasch N. Process for co-producing jet fuel and LPG from renewable sources. Washington: United States patent; 2010.

51. Kalnes TN, Mccall MM, Shonnard DR. Renewable diesel and jet-fuel production from fats and oils. In: Crocker M, editor. Thermochemical conversion of biomass to liquid fuels and chemicals. London: Royal Society of Chemistry; 2010.

52. Trejo-Zarrage F, de Jesus Hernandez-Loyod F, Sotelo-Boyás R. Hydroconversion of Triglycerides into Green Liquid Fuels. In: Karamé I, editor. Hydrogenation. Rijeka: INTECH; 2012.

53. Pearlson MN. A techno-economic and environmental assessment of hydroprocessed renewable distillate fuels. Thesis. Massachusetts Institute of Technology Department of Technology and Policy; 2011.

54. Veriansyah B, Han JY, Kim SK, Hong S-A, Kim YJ, Lim JS, Shu Y-W, Oh S-G, Kim J. Production of renewable diesel by hydroprocessing of soybean oil: effect of catalysts. Fuel. 2012;94:578-85.

55. Gary JH, Handwerk GE, Kaiser MJ. Petroleum refining, technology and economics. Boca Raton: CRC Press; 2007.

56. Brandvold TA, McCall MJ. Production of blended fuel from renewable feedstocks. Washington: United States patent; 2009.

57. Giannetto GE, Perot GR, Guisnet MR. Hydroisomerization and hydrocracking of n-alkanes. 1. Ideal hydroisomerization PtHY catalysts. Ind Eng Chem Prod Res Dev. 1986:25:481-90.

58. Park KC, Ihm SK. Comparison of Pt/zeolite catalysts for n-hexadecane hydroisomerization. Appl Catalys General. 2000;203:201-9.

59. International Air Transport Association. IATA 2010 report on alternative fuels. 5th ed. Montreal: International Air Transport Association; 2010.

60. U.S. Energy Information Administration. U.S. wholesale propane/resale price. Washington: U.S. Energy Information Administration; 2015.

61. U.S. Department of Energy. Alternative fuel price report. Washington: U.S Department of Energy; 2015.

62. Davis R, Tao L, Tan EC, Biddy MJ, Beckham G, Scarlata CJ, Jacobson J, Cafferty K, Ross J, Lukas J, et al. Process design and economics for the conversion of lignocellulosic biomass to hydrocarbons-dilute-acid and enzymatic deconstruction of biomass to sugars and biological conversion of sugars to hydrocarbons. Golden: National Renewable Energy Laboratory (NREL); 2013.

63. Humbird D, Davis R, Tao L, Kinchin C, Hsu D, Aden A, Schoen P, Lukas J, Olthof $\mathrm{B}$, Worley $\mathrm{M}$, et al. Process design and economics for biochemical conversion of lignocellulosic biomass to ethanol: dilute-acid pretreatment and enzymatic hydrolysis of corn stover. Golden: National Renewable Energy Laboratory (NREL); 2011.

64. AspenPlus ${ }^{\mathrm{TM}}$. Release 7.2. Cambridge: Aspen Technology Inc.; 2007.

65. Tao L, Wang W-C. Techno-economic analysis for upgrading the biomass-derived alcohols to jet blend stocks. Golden: National Renewable Energy Lab; 2013.

66. Tao L, Tan ECD, McCormick R, Zhang M, Aden A, He X, Zigler BT. Technoeconomic analysis and life-cycle assessment of cellulosic isobutanol and comparison with cellulosic ethanol and n-butanol. Biofuels, Bioproducts and Biorefining. 2013; . https://doi.org/10.1002/bbb.1431.

67. Chemical Engineering Magazine. Chemical Engineering Magazine Plant Cost Index; 2015.

68. Consulting S. U.S. producer price indexes_chemicals and allied products/industrial inorganic chemicals index. Menlo Park: Chemical Economics Handbook; 2008 
69. Bureau of Labor Statistics Data website (2009) National employment, hours, and earnings catalog. Industry: Chemicals and Allied Products, 1980-2009.

70. Dutta A, Talmadge M, Hensley J, Worley M, Dudgeon D, Barton D, Groenendijk P, Ferrari D, Stears B, Searcy EM, et al. Process design and economics for conversion of lignocellulosic biomass to ethanol, thermochemical pathway by indirect gasification and mixed alcohol synthesis. Golden: National Renewable Energy Laboratory; 2011.

71. Davis J, Haase S, Warren A. Waste to Energy evaluation: US Virgin lands. Golden: National Renewable Energy Laboratory (NREL); 2011.

72. Chemical Engineering Magazine. http://www.chemengonline.com/ pci-home.

73. SRI Consulting. U.S. producer price indexes_chemicals and allied products/industrial inorganic chemicals index. Menlo Park: Chemical Economics Handbook; 2008.

74. Bureau of Labor Statistics Data website, National employment, hours, and earnings catalog, industry: chemicals and allied products, 1980-2009. http://data.bls.gov/cgi-bin/srgate.

75. Aden A, Ruth M, Ibsen K, Jechura J, Neeves K, Sheehan J, Wallace B, Montague L, Slayton A, Lukas J: Lignocellulosic Biomass to Ethanol Process Design and Economics Utilizing Co-Current Dilute Acid Prehydrolysis and Enzymatic Hydrolysis for Corn Stover. In Other Information: PBD: 1 Jun 2002. pp. Medium: ED; Size: 154 pages; 2002: Medium: ED; Size: 154 pages.

76. Milbrandt A, Kinchin C, McCormick R. The feasibility of producing and using biomass-based diesel and jet fuel in the United States. Contract. 2013;303:275-3000.

77. Aden A, Ruth M, Ibsen K, Jechura J, Neeves K, Sheehan J, Wallace B, Montague L, Slayton A, Lukas J. Lignocellulosic biomass to ethanol process design and economics utilizing co-current dilute acid prehydrolysis and enzymatic hydrolysis for corn stover. In: Other Information: PBD: 1 Jun 2002. pp. Medium: ED; Size: 154 pages; 2002:Medium: ED; Size: 154 pages). http://www.nrel.gov/docs/fy020sti/32438.pdf

78. Richardson JW, Outlaw JL, Allison M. The economics of microalgae oil. AgBioForum. 2010;13:119-30.

79. Liu YY, Sotelo-Boyas R, Murata K, Minowa T, Sakanishi K. Hydrotreatment of vegetable oils to produce bio-hydrogenated diesel and liquefied petroleum gas fuel over catalysts containing sulfided ni-mo and solid acids. Energy Fuels. 2011;25:4675-85.

80. Dubois V, Breton S, Linder M, Fanni J, Parmentier M. Faty acid profiles of 80 vegetable oils with regard to their nutritional potential. Eur J Lipid Sci Technol. 2007;109:710-32.

81. Atabani AE, Silitonga AS, Ong HC, Mahlia TMI, Masjuki HH, Badruddin IA, Fayaz H. Non-edible vegetable oils: a critical evaluation of oil extraction, fatty acid compositions, biodiesel production, characteristics, engine performance and emissions production. Renew Sustain Energy Rev. 2013;18:211-45

82. Robota HJ, Alger JC, Shafer L. Converting algal triglycerides to diesel and HEFA JEt fuel fractions. Energy Fuels. 2013;27:985-96.

83. Tyson KS. Brown grease feedstocks for biodiesel. Golden: National Renewable Energy Laboratory; 2002.

84. Singh SP, Singh D. Biodiesel production through the use of different sources and characterization of oils and their esters as the substitute of diesel: a review. Renew Sustain Energy Rev. 2010;14:200-16.

85. Fatty acid composition of rapeseed and low erucic acid (canola) oil compared to olive oil, soybean and sunflower. ftp://ftp.fao.org/es/esn/ food/bio-10t.pdf.
86. Gerpen JV, Shanks B, Pruszko R, Clements D, Knothe G. Biodiesel production technology. Golden: National Renewable Energy Laboratory; 2004.

87. Canakci M, Van Gerpen J. Biodiesel production from oils and fats with high free fatty acids. Trans ASAE. 2001;44:1429.

88. Scaron M, Hluscaron J, Vollmann J, Jozef H, Flipcik R, Macek M, Kračmar S. Fatty acid composition of Camelina sativa as affected by combined nitrogen and sulphur fertilisation. Afr J Agric Res. 2011;6:3919-23.

89. Salimon J, Noor DAM, Nazrizawati A, Firdaus MM, Noraishah A. Fatty acid composition and physicochemical properties of Malaysian castor bean Ricinus communis L. seed oil. Sains Malaysiana. 2010;39:761-4.

90. Cao P, Dubé MA, Tremblay AY. High-purity fatty acid methyl ester production from canola, soybean, palm, and yellow grease lipids by means of a membrane reactor. Biomass Bioenerg. 2008;32:1028-36.

91. Zhang Y, Dube MA, McLean DD, Kates M. Biodiesel production from waste cooking oil: 2. Economic assessment and sensitivity analysis. Biores Technol. 2003;90:229-40.

92. Marchetti JM, Miguel VU, Errazu AF. Techno-economic study of different alternatives for biodiesel production. Fuel Process Technol. 2008;89:740-8.

93. Haas MJ, McAloon AJ, Yee WC, Foglia TA. A process model to estimate biodiesel production costs. Biores Technol. 2006:97:671-8.

94. Apostolakou AA, Kookos IK, Marazioti C, Angelopoulos KC. Technoeconomic analysis of a biodiesel production process from vegetable oils. Fuel Process Technol. 2009;90:1023-31.

95. Jones SB, Zhu Y. Preliminary Economics for the Production of Pyrolysis Oil from Lignin in a Cellulosic Ethanol Biorefinery. Richland: Pacific Northwest National Laboratory; 2009.

96. Richardson JW, Outlaw JL, Allison M. The economics of microalgae oil. J Agrobiotechnol Manag Econom. 2010;13:119-30.

97. Jones SB, Zhu Y. Preliminary Economics for the Production of Pyrolysis Oil from Lignin in a Cellulosic Ethanol Biorefinery. Pacific Northwest National Laboratory; 2009. http://citeseerx.ist.psu.edu/viewdoc/downlo ad?doi=10.1.1.597.7426\&rep=rep1\&type $=$ pdf.

98. Ash M. Oil crops outlook, soybean meal and oil prices moderate ahead of declining production. Washington: U. S. Department of Agriculture; 2013.

99. Natelson RH, Wang W-C, Roberts WL, Zering KD. Technoeconomic analysis of jet fuel production from hydrolysis, decarboxylation, and reforming of camelina oil. Biomass Bioenerg. 2015;75:23-34.

100. Johari A, Nyakuma BB, Mohd Nor SH, Mat R, Hashim H, Ahmad A, Yamani Zakaria Z, Tuan Abdullah TA. The challenges and prospects of palm oil based biodiesel in Malaysia. Energy. 2015;81:255-61.

101. Lestari D, Zvinavashe E, Sanders JPM. Economic valuation of potential products from Jatropha seed in five selected countries: Zimbabwe, Tanzania, Mali, Indonesia, and The Netherlands. Biomass Bioenerg. 2015;74:84-91.

102. Czernik S, Bridgwater AV. Overview of applications of biomass fast pyrolysis oil. Energy Fuels. 2004;18:590-8.

103. USDA Foreign Agricultural Services. Oilseeds: world markets and trade. Washington: USDA; 2015.

\section{Submit your next manuscript to BioMed Central and we will help you at every step:}

- We accept pre-submission inquiries

- Our selector tool helps you to find the most relevant journal

- We provide round the clock customer support

- Convenient online submission

- Thorough peer review

- Inclusion in PubMed and all major indexing services

- Maximum visibility for your research

Submit your manuscript at www.biomedcentral.com/submit 